Research

\title{
The effect of local ketamine infiltration on post tonsillectomy pain scale
}

\author{
Ade Asyari*, Novialdi*, Elniza Morina*, Rimelda Aquinas*, Nasman Puar**, \\ Hafni Bachtiar*** \\ *Department of Oto Rhino Laryngology Head and Neck Surgery, \\ **Department of Anesthesiology and Intensive Therapy \\ *** Department of Public Health \\ Faculty of Medicine Andalas University/M.Djamil General Hospital, \\ Padang
}

\begin{abstract}
Background: Post tonsillectomy pain is one of the surgery side effects that most disturbing for patient's comfort and will cause dysphagia, low intake, dehydration, secondary infection and bleeding. Ketamine is an anesthetic drug that has strong analgesic effect and easily available in any hospital at relatively cheap price. Objective: To find out the effect of local ketamine infiltration on the post tonsillectomy pain scale. Method: An experimental study during tonsillectomy with a Post Test Control Group on 12 samples without local infiltration of ketamine and 12 samples with local infiltration of ketamine in peritonsillar pillar. The pain was assessed 2 hours and 24 hours post extubation with pain Visual Analog Scale (VAS). Result: The VAS value from patients who were given local infiltration of ketamine in peritonsillar pillar were lower $(5.83 \pm 0.72$ at 2 hours and $2.83 \pm 0.58$ at 24 hours post extubation) compared to patients without ketamine infiltration $(7.83 \pm 0.58$ at 2 hours and $3.58 \pm 0.51$ at 24 hours post extubation). The result showed statistically significant difference $(p<0.05)$ at 2 hours and 24 hours post extubation. Conclusion: The VAS score of the ketamine infiltration group is lower at 2 hours and 24 hours post extubation than the group without ketamine infiltration, showing there was a noticeable effect of local ketamine infiltration on the post tonsillectomy pain scale.
\end{abstract}

Keywords : post tonsillectomy pain, ketamine, local infiltration, visual analog scale

\section{ABSTRAK}

Latar belakang: Nyeri pascatonsilektomi adalah salah satu efek samping operasi yang sangat mengganggu kenyamanan pasien, dan dapat menyebabkan gangguan menelan, kurangnya asupan nutrisi, dehidrasi, infeksi sekunder dan perdarahan. Ketamin merupakan obat anestesi yang memiliki efek analgetik yang kuat dan mudah didapatkan di semua tipe rumah sakit dengan harga yang relatif murah. Tujuan: Mengetahui efek pemberian infiltrasi lokal ketamin terhadap skala nyeri pascatonsilektomi. Metode: Penelitian eksperimental dengan desain Post Test Control Group pada 12 sampel tanpa pemberian infiltrasi lokal ketamin dan 12 sampel dengan pemberian infiltrasi lokal ketamin di pilar peritonsil saat tonsilektomi. Dilakukan penilaian nyeri 2 jam dan 24 jam pascaekstubasi menggunakan skala nyeri Visual Analog Scale (VAS). Hasil: Nilai VAS pasien yang diberi infiltrasi lokal ketamin di pilar peritonsil lebih rendah (5,83 $\pm 0,72$ pada 2 jam dan 2,83 $\pm 0,58$ pada 24 jam pascaekstubasi) dibanding tanpa diberi

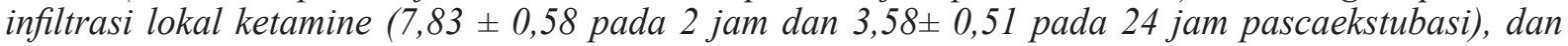
bermakna secara statistik $(p<0,05)$ pada kedua penilaian. Kesimpulan: Terdapat efek nyata infiltrasi lokal ketamin terhadap skala nyeri pascatonsilektomi, dimana nilai VAS kelompok yang diberi infiltrasi ketamin lebih rendah, baik pada 2 jam ataupun 24 jam pascaekstubasi dibanding kelompok yang tidak diberi infiltrasi ketamin. 
Kata kunci: nyeri pascatonsilektomi, ketamin, infiltrasi lokal, visual analog scale

Correspondence Address: Ade Asyari, Department of Oto Rhino Laryngology-Head and Neck Surgery, Faculty of Medicine Andalas University/Dr. M. Djamil General Hospital Padang. Email: adeasyari2@, gmail.com.

\section{INTRODUCTION}

Tonsillectomy is the complete removal of tonsils by making an incision in the tonsillar capsule, and the tonsillar tissue is dissected along with the capsule and surrounding tissue. ${ }^{1}$ Tonsillectomy is the most common performed Ear Nose and Throat (ENT) surgery worldwide. ${ }^{2-4}$

Tonsillectomy is often performed in children..$^{2-4}$ In 1917 Crowe cited by Ramzi et $\mathrm{al}^{5}$ recorded 1000 cases of tonsillectomy in Johns Hopkins Hospital. According to Schmitt \& Berman cited by Shutter ${ }^{6}$ tonsillectomy with or without adenoidectomy performed on nearly $1 / 3$ of children in the United States. In 2005-2006 more than 50,000 tonsillectomies were performed in England and Wales on indications of chronic tonsillitis. ${ }^{7}$ In $\mathrm{M}$. Djamil General Hospital Padang, there were 76 patients underwent tonsillectomy during the year $2014 .^{8}$

Tonsillectomy is usually executed due to recurrent tonsillitis, chronic obstructive tonsillar hypertrophy, history of peritonsillar abscesses and halitosis. ${ }^{3,9}$ Tonsillectomy is done by various techniques according to the operator's choice either by conventional means or using advanced technology such as thermal welding, coblation (controlled ablation), laser, and harmonic scalpel. Each technique has a different risk of surgery complications and pain. ${ }^{10,11}$

Pain in post tonsillectomy patients is caused by damage to the mucosa of tonsillar fossa which can cause inflammation and spasm of pharyngeal muscles, so it stimulates the free nerve endings of the glossopharyngeal nerves. It will further stimulate nociceptors that will send pain signals to the Central Nervous System (CNS) to generate pain. ${ }^{1,7}$

Post tonsillectomy pain is influenced by many factors. The surgical technique and equipment used will cause different surgical complications and pain as well. Conventional tonsillectomy techniques will cause different trauma to the tissue so that the resulting pain will be different compared to surgery using electrocautery, harmonic scalpel, thermal welding, laser or coblation. ${ }^{12,13}$

Various methods were developed to reduce pain and the risk of bleeding in post tonsillectomy. One of the methods is by giving infiltration drugs in peritonsillar pillar of post tonsillectomy patients. This measure is expected to be effective in reducing post tonsillectomy pain without any systemic effects. Ketamine is an anesthetic drug that has a strong analgesic effect. It can be given intravenously (IV), intramuscularly (IM) or subcutaneously and in tonsillectomy can be used as analgesics by infiltrating the peritonsillar or tonsillar fossa. In a meta analysis study conducted by Tong et al. ${ }^{14}$ in 2014 , it was found that the administration of local infiltration of ketamine in post tonsillectomy patients reduced pain scores without any side effects, nausea and vomiting. Ayatollahi et al. ${ }^{13}$ in 2012 obtained the pain scale in post tonsillectomy patients with administration of local ketamine infiltration was lower than patients in the control group. Khademi et al. ${ }^{15}$ in 2011 compared the administration of ketamine IV with local infiltration, finding that local infiltration of ketamine was better in coping with post tonsillectomy pain. 
According to the National Standards of Hospital Accreditation (SNARS = Standar Nasional Akreditasi Rumah Sakit) on Patient and Family Rights (HPK=Hak Pasien dan Keluarga), the hospital is obliged to do an appropriate pain assessment for the patients. Perceived pain can have unexpected effects both physically and psychologically. Therefore, optimal pain management in post tonsillectomy patients is essential. Research on local infiltration to control post tonsillectomy pain has never been done in Padang, particularly in Otorhinolaryngology Head and Neck Surgery Department, Faculty of Medicine, Andalas University. For this reason, the authors wanted to find out the effects of using ketamine local infiltration in post tonsillectomy patients. Ketamine is a pre-anesthetic induction drug which is always available in the operating room. Moreover, the price of ketamine is relatively cheap, so it will not increase the operational costs, and it is also considered safe due to its minimal side effects. The authors hoped that by administering this drug, the pain scale of post tonsillectomy patients will decrease for the sake of patient's comfort.

\section{METHOD}

This is an experimental research, conducted at the M. Djamil General Hospital, Padang and several type $\mathrm{C}$ hospitals in Padang from October 2018 to February 2019.

The population was all patients who underwent tonsillectomy surgery at M. Djamil General Hospital, Padang and several type $\mathrm{C}$ hospitals in Padang. Samples were taken by consecutive sampling with inclusion criteria: the patient was willing to sign written informed consent, the diagnosis was chronic tonsillitis, the operation procedure was only tonsillectomy, age over 14 years old, cooperative for VAS assessment, surgery was performed by dissection; and exclusion criteria were history of peritonsillar abscess, had contra indications to ketamine, tonsillar tumors, patients experiencing complications such as post tonsillectomy hemorrhage, or had a bleeding stopped by cauterization during surgery, and operating time of more than 1 hour.

Patients were divided into 2 groups: the treatment group who was given ketamine infiltration and the control group who was not given ketamine infiltration. All patients had been fasting for 6-8 hours prior to surgery. Before entering the operating room, the patient was given education about how to assess VAS. Preoperative Ceftriaxone antibiotics were administered half hour before surgery according to the recommended dosage preceded by a skin test. In the operating theatre, the patient was given premedication, intubated and anesthetized with N2O.

Tonsillectomy with dissection technique was performed by one operator. After tonsillectomy was completed, infiltration was performed at 3 sites in the peritonsillar pillar: top end, the base and in the middle. The group that received ketamine was given a dose of $0.5 \mathrm{mg} / \mathrm{kg}$ BW ketamine diluted with aquabidest up to a $10 \mathrm{cc}$. Ketamine was infiltrated with no.26G needle in an upright needle position, at the three sites of peritonsillar pillar on both sides. The control group was not given infiltration. In all groups, Paracetamol infusion was given $20 \mathrm{mg} / \mathrm{kg}$ $\mathrm{BW}$ in the recovery room. Tramadol drip is given 2 hours post extubation to 24 hours postoperatively at a dose of $1 \mathrm{mg} / \mathrm{kg} \mathrm{BW}$ after 8 hours.

\section{RESULT}

This study was conducted on patients with chronic tonsillitis who underwent tonsillectomy by providing ketamine infiltration post tonsillectomy in peritonsillar pillar, then evaluating a graded pain Visual Analog Scale (VAS) at 2 hours and 24 hours post extubation. This study included 12 
patients who were given ketamine injection in peritonsillar pillar as a treatment group and 12 patients who were not given ketamine infiltration as a control group. Both groups were given the same anesthetic drugs, as well as postoperative intravenous analgesics. In addition to the postoperative pain scale, side effects of drugs such as nausea, vomiting, palpitations and hallucinations were observed. Side effects of nausea and vomiting were found in 1 person in the control group and 1 person in the treatment group. The nausea effect was found in 1 person in the treatment group. Side effects such as tachycardia or hallucinations were not found in both groups.

Of the 12 patients in the control group, we obtained patients aged between 17 and 55 years old, whereas in the treatment group we obtained between 17 and 53 years old.
Characteristics of respondents based on gender and average age could be seen in Table 1.

Table 1 showed that more women in the control group $(66.7 \%)$, compared to the treatment group $(50 \%)$. More men $(50 \%)$ in the treatment group compared to the control group $(33.3 \%)$. There was no statistically significant difference $p>0.05$. Table 1 also showed the characteristics of the study subjects by age, where the average age of the two groups was almost the same, $30 \pm 10.90$ and $30.5 \pm 13.95$. Statistically, there was no significant difference $\mathrm{p}>0.05$.

From this study, the mean and standard deviation of post tonsillectomy pain scale at 2 hours and 24 hours postoperative was shown in Table 2.

Table 1. Characteristics of respondents by gender and mean age

\begin{tabular}{lccc}
\hline \multirow{2}{*}{ Characteristic } & Control group & Treatment group & p-value \\
\cline { 2 - 3 } & $\mathbf{f ( \% )}$ & $\mathbf{f ( \% )}$ & \\
\hline Gender & & & 0.679 \\
Male & $4(33.3)$ & $6(50)$ & \\
Female & $8(66.7)$ & $6(50)$ & 0.656 \\
\hline $\begin{array}{l}\text { Mean age } \\
\text { (years) }\end{array}$ & $30 \pm 10.90$ & $30.5 \pm 13.95$ & \\
\hline
\end{tabular}

Table 2 showed the differences in the scale of VAS values post tonsillectomy of control group and the treatment group at 2 hours and 24 hours post extubation. At 2 hours post extubation, the mean pain scale score of treatment group was lower than the control group, VAS in the treatment group was $5.83 \pm 0.71$ and control group was 7.83 \pm 0.57 . There was a statistically significant difference between the pain scale of the VAS group in control group treatment at 2 hours post extubation $(p<0.05)$. At 24 hours post extubation, the mean value of the treatment group was lower than the control group. VAS of the control group was $3.58 \pm 0.51$, whereas in the treatment group the value of the VAS was $2.83 \pm 0.57$. Statistically, there were significant differences between the VAS values of the control group and the treatment group $(\mathrm{p}<0.05)$.

The lowest VAS value on 2 hours post extubation in the treatment group was 5 and the highest VAS value was 7 . While in the control group the lowest VAS value 2 hours post extubation was 7 and the highest value was 9. At 24 hours postoperative, the lowest VAS value in the treatment group was 2 and the highest VAS was 4, while the lowest VAS value on the control group was 3 and the highest value was 4 . 
Table 2. Differences in post tonsillectomy VAS values in the control and treatment groups

\begin{tabular}{cccc}
\hline \multirow{2}{*}{ Assessment time } & \multicolumn{2}{c}{ VAS pain scale } & \\
\cline { 2 - 3 } & $\begin{array}{c}\text { Control group } \\
(\text { Mean } \pm \text { SD) }\end{array}$ & $\begin{array}{c}\text { Treatment group } \\
\text { (Mean } \pm \text { SD) }\end{array}$ & p-value \\
\hline 2 hours post extubation & $7.83 \pm 0.57$ & $5.83 \pm 0.71$ & $<0.001$ \\
\hline 24 hours post extubation & $3.58 \pm 0.51$ & $2.83 \pm 0.57$ & 0.03 \\
\hline
\end{tabular}

\section{DISCUSSION}

This was an experimental study with a Post Test Control Group to determine the effect of ketamine infiltration on the post tonsillectomy pain scale. This study compared the VAS between the group of patients who were given ketamine infiltration (treatment group) and the group who were not given ketamine infiltration (control group). Ketamine infiltration was administered 0.5 $\mathrm{mg} / \mathrm{kgBW}$ in peritonsillar pillar and assessed the pain scale with VAS after 2 hours and 24 hours post extubation. Both groups were given the same intravenous analgesics, and also the same anesthetic drugs, which were given according to bodyweight dose.

Pain assessment in this study was done with VAS because VAS is a pain measurement tool that is easy to do, can be performed anytime, and has been validated to assess the scale of pain in various situations such as when waking up or when in anxious state. By using the VAS, the change in pain scale can be detected immediately. Until now there has not been an objective pain gauge, but with VAS it is expected that patients can determine their own level of pain with a simple tool and can be reused. ${ }^{16}$ But VAS cannot be used to assess pain in children, so this study used samples over 14 years old of age.

To assess pain besides using VAS, a Verbal Numerical Rating Scale (VNRS) can be utilised. Almost the same as VAS, VNRS also uses a scale of 1-10 to assess pain without using a ruler like VAS. As for children, children can use the Faces Leg Activity Cry Consolability (FLAC) or the Wong-Baker FACES Score. For SNARS, pain assessment in adults is done by VAS and VNRS.

The number of women in the control group was higher than in the treatment group. While the number of men in the treatment group was more than in the control group. In this study we included patients over 14 years old, who needed tonsillectomy without adenoidectomy, there was no history of peritonsillar abscess and the duration of surgery was not more than 1 hour. Several studies stated that women are more sensitive to pain. According to Filingim et al. ${ }^{17}$ and Bartley et al. ${ }^{18}$ women are more sensitive to pain than men. In this study, there was no statistically significant difference between the two groups with respect to gender or age.

In our study, the mean pain scale with VAS assessment at 2 hours post extubation in the control group was $7.83 \pm 0.57$ and the treatment group was $5.83 \pm 0.71$. Statistically, there were significant differences between the two groups. From the results, it was found that the pain scale of patients given ketamine infiltration in peritonsillar pillar had a lower mean VAS than of patients without infiltration either 2 hours or 24 hours postoperative. This study is in accordance with Honarmand ${ }^{19}$ which found that the pain scale of patients who were given two doses of pre-incisional ketamine infiltration was lower than the 
control group (the group which was given normal saline infiltration) without significant side effects. Ketamine is a drug commonly used for pre-anesthesia induction. This drug has a strong analgesic effect. Ketamine has central and peripheral effects. If ketamine was given by local or topical infiltration it will cause higher tissue concentration compared to systemic administration and has a low affinity and slow absorption into the blood circulation. With this, it is hoped that the anesthetic effect will last longer and avoid high levels in the blood. $^{20}$

Local infiltration of ketamine inhibits the peripheral canal of sodium, calcium, and potassium. Besides, by giving locally the function of ketamine as glutamate N-methyld-aspartate (NMDA) receptor blockers will also reduce pain. Glutamate receptors are also found at the nerve endings, and inflammation response and tissue damage will cause an increase of glutamate release at the primary afferent nerve end. ${ }^{21}$

At 24 hours post extubation the mean VAS of control group was $3.58 \pm 0.51$, whereas in the treatment group the VAS value was $2.83 \pm 0.57$. Statistically, there were significant differences between the two groups. Honarmand ${ }^{19}$ found that local infiltration of ketamine post tonsillectomy could have analgesic effects for up to 24 hours post tonsillectomy. Sonbaty et al. ${ }^{22}$ conducted a study of post tonsillectomy patients by dividing patients into 4 groups, those who were given ketamine, meperidine, meperidine plus bupivacaine, and ketamine plus bupivacaine. They found that the pain scale of patients with ketamine infiltration was lower than the patients which were given meperidine, whereas those given ketamine infiltration mixed with bupivacaine had lower pain scales than those of ketamine, meperidine, and meperidine mixed with bupivacaine group.

Khademi et al. ${ }^{15}$ who conducted a study comparing the VAS of post tonsillectomy patients by providing intravenous ketamine and local infiltrated ketamine found that local infiltrated ketamine was more effective in reducing pain without side effects such as nausea and vomiting. Erhan et al. ${ }^{23}$ found that there were significant differences in pain scale between administration of ketamine infiltration and normal saline in post tonsillectomy patients.

Cho et al. ${ }^{24}$ conducted a meta analysis of the administration of ketamine in post tonsillectomy children by evaluating pain and drug side effects. They found that intravenous ketamine and local infiltration both reduced the post tonsillectomy pain scale, but local infiltration was more effective in reducing pain and had a longer effect than intravenous administration, which was 6-24 hours.

Management of pain in post tonsillectomy patients is very important to prevent complications such as secondary bleeding, infection, shorten the length of hospitalization and speed up the patient to start normal activities. In children, post tonsillectomy pain will cause odynophagia, lack of food intake, dehydration, nausea, vomiting, bleeding and secondary infections. Alhamarneh et al. ${ }^{25}$ found that the occurrence of secondary bleeding was more significant in patients who received inadequate analgesics, therefore adequate administration of analgesics was important to prevent secondary bleeding. Sonbaty et al..$^{22}$ found that the length of stay of patients who were given ketamine infiltration was shorter than that of meperidine or meperidine mixed with bupivacaine, and there was no significant difference between those receiving ketamine infiltration and ketamine bupivacaine mixture.

This study showed differences of pain scale, both in the control group and in the treatment group. In the treatment group the pain scale ranged from 5 to 7 . In the control group the pain scale ranged from 7 to 9 . Many factors affect the assessment of the pain scale, the literature mentioned surgery 
technique, age, gender, indications of surgery, psychological state of patients, and genetic factors. Zagolsky et al. ${ }^{26}$ compared post tonsillectomy pain based on tonsillectomy indications, found that the pain scale of patients with recurrent tonsillitis was lower than patients with other tonsillectomy indications. In his study, all samples were adults with the same techniques and operators.

According to the American Academy of Otolaryngology-Head \& Neck Surgery (AAO-HNS), Paracetamol is effective for treating post tonsillectomy pain, ${ }^{27}$ but in our study, it appears that the pain scale of patients who received Paracetamol infusion without being given ketamine infiltration is still quite high, with the highest VAS value of 8 .

Based on SNARS, the pain scale of postoperative inpatient should be maintained below 4. From this study, it was seen that the use of local ketamine infiltration in peritonsillar anterior pillar could be an alternative for post tonsillectomy pain management combined with other analgesics. However, local infiltration of ketamine has not been able to reduce the pain scale to the maximum. Thus, local administration of post tonsillectomy ketamine infiltration still requires additional analgesics.

From some literatures, it is known that the administration of a combination of ketamine with other local analgesics showed better results in suppressing the pain scale post tonsillectomy and will prolong the effect of drug in tissue. Therefore, further research is needed by using a combination of ketamine and other local anesthetics for the management of post tonsillectomy pain.

It can be concluded from this study that the pain scale in control group was severe pain at 2 hours and mild pain at 24 hours post tonsillectomy. The pain scale in the treatment group was moderate pain at 2 hours and mild pain at 24 hours post tonsillectomy. There was a local infiltration effect of ketamine on the post tonsillectomy pain scale where the VAS value of the treatment group is lower at 2 hours and at 24 hours post extubation compared to the control group. Statistically, there were significant differences between the two groups.

\section{REFERENCE}

1. Cohen N, Sommer DD. Post-tonsillectomy pain control: consensus or controversy? Pain Manag. 2016; 6(1): 31-7.

2. Stelter K, Hiller J, Hempel JM, et al. Comparison of two different local anaesthetic infiltrations for postoperative pain relief in tonsillectomy: a prospective, randomised, double blind, clinical trial. Eur Arch Otorhinolaryngol. 2010; 267(7):1129-34.

3. Topal K, Aktan B, Sakat MS, Kilic K, Gozeler MS. Post-operative pain control after tonsillectomy: dexametasone vs tramadol. Acta Otolaryngol. 2017; 137(6): 618-22.

4. Alvares I, Gonzales R, Martinez C, Ayala A, Arenas O. Postoperative Pain in Adult Tonsillectomy: Is There Any Difference Between the Technique ? Indian J Otolaryngol Head Neck Surg. 2017;(January 2017):1-7.

5. Younis RT, Lazar RH. History and current practice of tonsillectomy. Laryngoscope. 2002;112:3-5.

6. Sutters KA, Miaskowski C. Inadequate Pain Management and Associated Morbidity in Children at Home After Tonsillectomy. J Pediatr Nurs. 1997;12(3):178-85.

7. Grainger J, Saravanappa N. Local anaesthetic for post-tonsillectomy pain: A systematic review and meta-analysis. Clin Otolaryngol. 2008;33(5):411-9.

8. Sari AM. Deteksi Biofilm Bakteri Aerob pada Usapan Tonsil Dengan Metode Tube pada Penderita Tonsilitis Kronis. Tesis. 2015: 1-4.

9. Jayakumar A. Disease in Children. In: Margareta C, ed. Bailey's Head \& Neck Surgery Otolaryngology. 5th ed. Philadelphia; 2014:1430-43. 
10. Walijee H, Al-hussaini A, Harris A, Owens D. What Are the Trends in Tonsillectomy Techniques in Wales? A Prospective Observational Study of 195 Tonsillectomies over a 10-Year Period. Int J Otolaryngol. 2015;747403:1-7.

11. Gurpinar B, Salturk Z, Akpinar ME, Yigit O, Turanoglu A. Comparison of Tonsillectomy Techniques and their Histopathological Healing Patterns. Otolaryngol open J. 2017;3(3):47-53.

12. Stelter K, Martin J,Alexander H,Andratschke M, Luebbers CW, Hagedorn H.Application methods of local anaesthetic infiltrations for postoperative pain relief in tonsillectomy : a prospective, randomised, double-blind, clinical trial. Eur Arch Otorhinolaryngol. 2009;266:1615-20.

13. Ayatollahi V, Behdad S, Hatami M, Moshtaghiun H, Baghianimoghadam B. Comparison of peritonsillar infiltration effects of ketamine and tramadol on post tonsillectomy pain: a double-blinded randomized placebo-controlled clinical trial. Croat Med J. 2012;53(2):155-61.

14. Tong $\mathrm{Y}$, Ding XB, Wang $\mathrm{X}$, Ren $\mathrm{H}$, Chen ZX, Li Q. Ketamine peritonsillar infiltration during tonsillectomy in pediatric patients: An updated meta-analysis. Int J Pediatr Otorhinolaryngol. 2014;78(10):1735-41.

15. Khademi S, Ghaffarpasand F, Heiran HR, Yavari MJ, Motazedian S, Dehghankhalili M. Intravenous and peritonsillar infiltration of ketamine for postoperative pain after adenotonsillectomy: A randomized placebocontrolled clinical trial. Med Princ Pract. 2011;20(5):433-7.

16. Ismail A, Ghafar A, Shamsuddin N, Rosland N, Kaharuddin I, Muhamad N. The assessment of acute pain in prehospital using verbal numeric, rating and visual analogue scales. J Emerg Med. 2015;(February):1-7.

17. Fillingim RB, King CD, Ribeiro-dasilva MC, Rahim- B, Riley JL. Sex, Gender and Pain:A Review of Recent Clinical and Experimental Findings. J Pain. 2009;10(5):447-85.
18. Bartley EJ, Fillingim RB. Sex differences in pain: a brief review of clinical and experimental findings. $\mathrm{Br} \mathrm{J}$ Anaesth. 2013;111(1):52-58.

19. Honarmand A, Reza M, Jamshidi M. The preventative analgesic effect of pre incisional peritonsillar infiltration of two low doses of ketamine for postoperative pain relief in children following adenotonsillectomy. A randomized. Pediatr Anesth. 2008;18:50814.

20. Schmid RL, Sandler AN, Katz J. Use and efficacy of low-dose ketamine in the management of acute postoperative pain: a review of current techniques and outcomes. Pain. 1999;82:111-25.

21. Sawynok J. Topical and peripheral ketamine as an analgesic. Anesth Analg. 2014;119(1):170-8.

22. El Sonbaty MI, El Dahab HA, Mostafa A, Shanab OA. Preemptive peritonsillar ketamine infiltration: Postoperative analgesic efficacy versus meperidine. Middle East J Anesthesiol. 2011;21(1):43-51.

23. Erhan L, Goksu H, Alpay C, Bestas A. Ketamine in post-tonsillectomy pain. Int $\mathrm{J}$ Pediatr Otorhinolaryngol. 2007;71:735-9.

24. Cho HK, Kim KW, Jeong YM, Lee HS, Lee YJ, Hwang SH. Efficacy of Ketamine in Improving Pain after Tonsillectomy in Children: Meta-Analysis. PLoS One. 2014;9(6):1-14.

25. Alhamarneh O, Raja H, England RJA. Inadequate analgesic prescription increases secondary post-tonsillectomy bleed rates: a completed audit loop. J Laryngol Otol. 2008;122:719-21.

26. Zagólski O, Gajda M, Strek P, Kozlowski MJ, Gadek A, Nyzio J. Adult tonsillectomy: postoperative pain depends on indication. Braz J Otorhinolaryngol. 2016;82(5):589-95.

27. Baugh RF, Archer SM, Mitchell RB, Rosenfeld RM, Amin R, Burns JJ, et al. Clinical Practice Guideline: Tonsillectomy in Children. Otolaryngol Head Neck Surg. 2011;144(IS):1-30. 